\section{Failure of Subarachnoid Blocks}

Hugo Praxedes, M.D., Antonio Leite Oliva Filho, TSA, M.D.

\section{INTRODUCTION}

"Experienced professional, healthy patient, correct technique, single puncture, adequate CSF backflow, effective anesthetic agent! So, why did it failed? - Capriciousness!!" (launehaft), that was the expression used by August Bier ${ }^{1}$, the first professional to use subarachnoid block and publish his experience 110 years ago referring to the wide variation in the dispersion of cocaine solutions among patients and the quality of the results observed. Modern scientific concepts do not accept such an imprecise justification for an unpredicted failure. And what is subarachnoid failure? According to Munhall et al. ${ }^{2}$, failure is seen after the anesthetics has been deposited in the subarachnoid space, confirmed by adequate CSF backflow, whenever general anesthesia is necessary to continue the surgical procedure without causing pain to the patient, regardless whether the failure is complete, incomplete, or the level is not enough, excluding situations that require mild sedation with opioids or benzodiazepines to offer comfort for a responsive patient.

Since its clinical introduction, several publications including prospective and retrospective studies with some consensus regarding the criteria used to define failure have reported a wide range of failure rates (Chart I). However, they all lack a precise cause-effect relationship.

This analysis brings a feeling similar to that mentioned by Hoppe and Popham: "After reviewing a number of cases over several years in which uneventful spinal blocks failed completely for no apparent reason, a literature search was conducted in an effort to explain the apparently inexplicable ${ }^{9}$. "Success of the spinal block requires the deposit of the correct dose of the proper drug in the CSF contiguous to the medul- lary cone and cauda equina, without physical, physiological, or biochemical barriers that would prevent the know effects of said drug on the nerve structure or, in other words, the right dose of the right agent in the right place." Hoppe and Popham ${ }^{9}$ were also extremely precise when they proposed this definition of successful spinal block. Similarly, Lorenzo ${ }^{10}$ stated a long time ago that failures were a result of: (1) lack of contact between the anesthetic and nerve structures; (2) administration of low volume or concentration of the anesthetic; (3) using attenuated anesthetic secondary to aging of the solution (repeated autoclaving); or (4) inadequate patient positioning after the spinal injection.

\section{The Right Place}

In this technique, the subarachnoid membrane is the most important structure, since the local anesthetic has to be deposited inside it where the CSF circulates. Its justadural external surface composed of multiple layers of firmly adhered epithelial cells, and not the dura mater, is considered the main barrier to the crossing of any substance from the epidural space to the cerebrospinal fluid (CSF) ${ }^{1}$. The other surface is trabeculated and has a spider web distribution over the pia mater. Besides constituting the CSF compartment, the arachnoid membrane is active in enzymatic inhibition and transport of drugs, neurotransmitters, or effectors accessing this space. In the elimination phase of local anesthetics or opioids, which begins as soon as they deposit in the effector site, most of the exchanges between the subarachnoid and epidural spaces are done at the level of the neural sheaths that surround the emergence of each nerve root. A correctly placed anesthetic agent, either by the proper needle or catheter, inside the subarachnoid space is contiguous to nerve structures (medullary cone, nerve roots, and cauda equina), facilitating its penetration and action at the level of the axonal membrane, where it blocks nerve conduction.

The rationale is simple, but it is not always achieved. To reach the interior of the subarachnoid space, the tip of the needle has

Chart I - Publications on Subarachnoid Block Failures

\begin{tabular}{|c|c|c|c|}
\hline Author & Year & Failure rate (\%) & Definition of failure \\
\hline Moore DC et al. ${ }^{3}$ & 1968 & $0.48 \%$ (tetrac) $^{*}$ & Insufficient level before the surgery \\
\hline Moore DC ${ }^{4}$ & 1980 & $0.82 \%$ (bupiv) $\# 16.6 \%$ (tetrac) & Pain during scheduled surgery \\
\hline Levy $\mathrm{JH}^{5}$ & 1985 & $17.00 \%$ (tetrac) & Conversion to general anesthesia \\
\hline Manchikanti et al. ${ }^{6}$ & 1987 & $1.6 \%$ (lido) $8.4 \%$ (tetrac) & Need of supplementation \\
\hline Munhall RJ et al.2 & 1988 & $4.00 \%$ (tetrac) & Conversion to general anesthesia \\
\hline Tarkkila JP et al. ${ }^{7}$ & 1991 & $\begin{array}{l}2.6 \% \text { (hyper lido) } \\
3.10 \% \text { (hyper and iso bupi) }\end{array}$ & Insufficient level, total failure, insufficient time \\
\hline Imbelloni LE et al. ${ }^{8}$ & 1995 & $7.05 \%$ (lido) and $9 \%$ (hyper or iso bupi) & $\begin{array}{l}\text { Absence of analgesia, insufficient level, pain on } \\
\text { visceral traction, insufficient time }\end{array}$ \\
\hline
\end{tabular}

tetrac = tetracaine; lido = lidocaine; bupi = bupivacaine; hyper = hyperbaric ; iso = isobaric.

*In the 1968 study by Moore, the following agents were investigated: procaine, dibucaine, piperocaine, and tetracaine. Failure analysis of 12,386 obstetric and surgical patients was undertaken; 11,907 of them were anesthetized with tetracaine, as a single agent or associated with one of the others, especially procaine and chloroprocaine.

\#In the 1980 study by More, results refer to $7.5 \mathrm{mg}$ for the two drugs compared. With the 12-mg dose, the failure rate between both drugs did not differ. 
to cross several tissues. During its trajectory, it can encounter obstacles like bone, ligament, or postural deformities that can stop the needle or deviate it from the original route. During this trajectory, perforation of the anesthetic "pouch" created by excessive infiltration of the tissues before the puncture is possible ${ }^{9}$. This will cause a backflow of clear fluid, leading to positioning error. Cysts in the region can be seen in $4.5 \%$ to $9.5 \%$ of the population ${ }^{9}$. Hoppe and Popham ${ }^{9}$ mentioned several types of cysts that can lead to a false interpretation of the position of the tip of the needle: synovial, dermoid, or ganglion cysts, Tarlov cysts, or cystic neuromas.

Accidental needle mobilization (especially small-caliber needles) during maneuvers to connect the anesthetic-containing syringe or during injection of the solution, can remove the tip of the needle from the subarachnoid space, leading to administration at the wrong site. The length of the bevel of the needle can also contribute with the failures. If a long bevel is partially introduced into the subarachnoid space, free flow of CSF is observed, but, during the injection, part of the anesthetic solution can remain outside the space, leading to a result different than that expected ${ }^{9}$. The same can be seen with pencil-tip needles with larger lateral holes, such as proposed by Sprotte. In those situations, the failure is most likely partial (inadequate blockade or insufficient sensorial level). This is more common with inexperienced professionals, but this is not always true. Introducing the needle a little deeper after the backflow of CSF to guarantee that the tip of the needle is entirely within the subarachnoid space as well as the observation of free flow of CSF before the administration intermittently during the injection, and post-injection, can prevent this types of failure.

Apparently, the gauge of the needle is one of the factors that hinder fixation during the injection and the correct identification of CSF backflow. In the study of Imbelloni ${ }^{8}$ (Chart I) in which the caliber of the needle was included in the observations of failure, the $25 \mathrm{G}$ needle was associated with a significantly lower incidence than $27 \mathrm{G}$ and $29 \mathrm{G}$ needles. Note that only experienced professionals participated in the study.

Although the dura mater-arachnoid membrane adhesion is firm, it is fragile, and detachment during insertion of the needle can occur. This can lead to the subdural administration of the anesthetic, reflecting on complete failure ${ }^{9}$.

Although a simple pre-anesthetic method to evaluate the volume of CSF of a patient does not exist, one of the reported causes of failure is the possibility that the volume of CSF is higher than average. Higher CSF volumes will result in smaller anesthetic level when fixed doses of the anesthetic agent are used 12,13 .

\section{The right Agent}

A wide variety of anesthetics has been, or still is, used in subarachnoid blocks (Chart II), starting with cocaine, adopted by Bier in his investigations since the first publication 110 years ago ${ }^{1}$. It evolved to procaine, a synthetic product, which was used at the beginning of the last century $(1915)^{14}$, until an-
Chart II - Local anesthetics, Except Cocaine, Used in Subarachnoid Blocks: Number of Publications, from the Oldest to the Most Recent, for Each Drug

\begin{tabular}{llc}
\hline & Period & Publications \\
\hline Amino-esters & & \\
Procaine & $1931-2008$ & 168 \\
Chloroprocaine & $1964-2008$ & 26 \\
Tetracaine & $1949-2008$ & 388 \\
Aminoamides & & \\
Lidocaine & $1956-2009$ & 808 \\
Prilocaine & $1964-2009$ & 99 \\
Bupivacaine & $1968-2009$ & 1423 \\
Etidocaine & $1993-1996$ & 3 \\
Ropivacaine & $1994-2009$ & 89 \\
Levobupivacaine & $1999-2002$ & 45 \\
S75R25* & 2002 & 1 \\
\hline
\end{tabular}

* $50 \%$ Enantiomeric excess bupivacaine.

Sources: Medline, Brazilian Journal of Anesthesiology.

other amino-ester, tetracaine, was coronated at the end of the last century ${ }^{15}$. Therefore, a short-acting - procaine - and a long-acting - tetracaine - agents were available. In 1953, lidocaine was synthesized: a new series of agents was born, the aminoamides. With an intermediate duration of action and free of allergic sensitization, it became a preference ${ }^{16}$ for almost five decades, until it was accused, along with microcatheters or small gauge needles, to cause neurologic manifestations, generically called TNS - transitory neurologic symptoms.

With the advent of bupivacaine in 1956, it progressively assumed the leadership in number of publications in its different presentations, hyperbaric or isobaric, racemic, levorotatory, or $50 \%$ enantiomeric excess. Chart II shows that lidocaine and bupivacaine represent the two agents studied more often in subarachnoid blocks by anesthesiologists all over the world with 808 publications for the former, and 1,423 publications for the latter. Besides, they represent the two drugs used more often by Brazilian anesthesiologists in this technique. The use of bupivacaine in spinal blocks is much higher than that of lidocaine. We can estimate the percentage by extrapolating the proportion of sales of both agents from 2005 to 2008, information kindly provided by the Cristália Laboratory (Chart III).

In the study of Levy et al. ${ }^{5}$ (Chart I), undertaken at a university hospital, 100 consecutive subarachnoid blocks were evaluated to determined the correlation between failures and patient characteristics, needle used, number of puncture at-

Chart III - Local Anesthetics Used in Brazil (percentage)

\begin{tabular}{lc}
\hline Local anesthetic & $\%$ \\
\hline Heavy bupivacaine 0.5\% & $96 \%$ \\
Heavy lidocaine 5\% & $4 \%$ \\
Total & $100 \%$ \\
\hline
\end{tabular}

Information provided by the Cristália Laboratory based on volume of distribution. 
tempts, and others, including the anesthetic agent used. Tetracaine was used in 78 patients; in 29 patients it was associated with epinephrine, and in 36 it was not associated with a vasoconstrictor. Lidocaine was used in 22 patients, 18 of which received pure lidocaine and in one it was associated with epinephrine. A significant difference was observed only in the group of tetracaine without epinephrine, with $25 \%$ of failures against only $6.45 \%$ when associated with vasoconstrictor.

The study by Imbelloni et al. ${ }^{8}$ (Chart I) also tried to correlate anesthetic agents and failure rates. They observed $9.23 \%$ of failures with bupivacaine and $6.64 \%$ with lidocaine, but statistically significant differences were observed only when hyperbaric and isobaric solutions were compared. The failure rate was lower with isobaric solutions. They also compared products manufactured by two different laboratories, but they did not observe any differences.

In a prospective study by Tarkilla ${ }^{7}$ (Chart I) with 1,891 spinal blocks performed at a university hospital with failure rates ranging from $2.6 \%$ to $3.1 \%$, significant differences were not observed between agents (lidocaine and bupivacaine) or baricity (iso- or hyperbaric bupivacaine).

Note that the definition criteria of failure used by those different authors varied, but they all agreed to consider failure whenever the regional technique had to be converted in general anesthesia. Considering those parameters, even though failure rates differed among the different studies due to standardization of different criteria, the anesthetic agent by itself did not influence the results. Some statistical difference was observed when differences in baricity of the same agent were evaluated or when the drug was associated or not with adrenaline. In other words, adjuvant agents either by the lack or addition were more often the cause of partial anesthesia failure than the anesthetic agents.

Another factor, other than the quality of the anesthetic agent, deserves attention when analyzing failures: the stability of the anesthetic solution in face of the length and type of storage. Amino-esters (procaine, tetracaine, or chloroprocaine) are more unstable than aminoamides (lidocaine, prilocaine, bupivacaine, or ropivacaine). The use of drugs in the first group should be limited to no more than two years from the date of manufacture. Three years is admissible for aminoamides. The place of storage is also important: anesthetic solutions should be protected from any type of ionizing radiation, including heat and light. Therefore, they should be stored in a cool environment protected from light ${ }^{17}$. If sterilization of the flasks in an autoclave is an option, it should use a maximal pressure of 1.5 atm (20 PSI or 138 kilopascal) during 30 minutes at $126{ }^{\circ} \mathrm{C}^{17}$. Repeating the sterilization in autoclave or for a longer time promote caramelization of the glucose in hyperbaric solutions. Fortunately, the agents are available in sterile containers.

The temperature of the anesthetic solution, especially if warmed to body temperature $\left(37^{\circ} \mathrm{C}\right)$, produces more extensive blockades than solutions at low temperature.

Some hypotheses have been made regarding the relationship between the $\mathrm{pH}$ of the CSF and that of the anesthetic solution and the density of the CSF and that of the anesthetic solution, although specific studies are lacking. Those derive from hypothesis determined in experimental studies that are nonreproducible in subarachnoid blocks.

\section{The Right Dose}

A study by Daniel Moore ${ }^{4}$ compared two different doses, depending on whether it was an intra- or extra-abdominal surgery, of bupivacaine and tetracaine. When comparing the smaller doses $(7.5 \mathrm{mg})$, for extra-abdominal surgeries, the rate of failure of tetracaine was higher than that of bupivacaine (16.6\% vs. $0.82 \%)$. Differences between both groups were not observed when higher doses of both agents, $12 \mathrm{mg}$, were used.

It has been shown that the dose of the anesthetic, more than the volume or concentration, is essential to determine the extension of the subarachnoid blockade ${ }^{18}$. Concentration is related with the quality of the blockade, from analgesia with low concentrations, to intense motor blockade with higher concentrations. Variation in the volume injected does not interfere with the extension of the blockade ${ }^{18}$.

\section{CONCLUSIONS}

Although spinal block is a centenary technique, used universally by specialists and non-specialists, and considered easy to execute by the majority of the professionals, it is subjected to occasional failure due to one of the several factors mentioned, even with highly skilled professionals. However, failures are more often due to technical factors. Therefore, proper evaluation of the anatomy of the patient related to the procedure, judicious choice of needle and puncture site, careful storage of anesthetic agents, selection of the dose and baricity, along with correct positioning of the patient during the puncture and shortly after the administration of the local anesthetic and until it is fixed to the tissue, to achieve better results. But even with increased care and ability, failures secondary to difficult to predict or intangible factors of current evaluation routines, i.e., the presence of a cyst in the trajectory of the needle and higher than expected CSF volumes, still occur.

\section{REFERÊNCIAS - REFERENCES}

1. Bier A.- Versuche über kokainiserung des ruchenmarkes. Dtsche $Z$ Chir 1899;51:361-9; citado em Di Cianni S, Rossi M, Casati A et al. Spinal anesthesia: an evergreen technique. Acta Biomed Ateneo Parmense 2008;79:9-17.

2. Munhall RJ, Sukhani R, Winnie AP. Incidence and etiology of failed spinal anesthetics in a university hospital: a prospective study. Anesth Analg 1988;67: 843-848.

3. Moore DC, Bridenbaugh LD, Bagdi PA et al. The present status of spinal (subarachnoid) and epidural (peridural) block: a comparison of the two technics. Anesth Analg 1968;47:40-49.

4. Moore DC. Spinal anesthesia: bupivacaine compared with tetracaine. Anesth Analg, 1980;59:743-750. 
5. Levy JH, Islas JA, Ghia JN et al. A retrospective study of the incidence and causes of failed spinal anesthetics in a university hospital. Anesth Analg 1985; 64:705-710.

6. Manchikanti L, Hadley C, Markwell SJ et al. A retrospective analysis of failed spinal anesthetic attempts in a community hospital. Anesth Analg 1987;66:363-366.

7. Tarkkila PJ. Incidence and causes of failed spinal anesthetics in a university hospital: a prospective study. Reg Anesth 1991;16:48-51.

8. Imbelloni LE, Sobral MGC, Carneiro ANG. Incidência e causas de falhas em anestesia subaracnóidea em hospital particular: estudo prospectivo Rev Bras Anestesiol 1995;45:159-164.

9. Hoppe J, Popham P. Complete failure of spinal anaesthesia in obstetrics. Int J Obstet Anesth 2007;16:250-255.

10. Lorenzo, AV. Falhas da raquianestesia. Rev Bras Anestesiol 1978;28:347-358.

11. Liu SS, McDonald SB. Current issues in spinal anesthesia. Anesthesiology, 2001;94:888-906.

12. Carpenter RL, Hogan QH, Liu SS et al. Lumbosacral cerebrospinal fluid volume is the primary determinant of sensory block extent and duration during spinal anesthesia. Anesthesiology 1998;89:24-29.

13. Hirabayashi $Y$, Fukuda $H$, Saitoh $K$ et al. Failed spinal anaesthesia: cause identified by MRI. Can J Anaesth 1996;43:1072-1075.

14. Harris A, Goldberg LG. Spinal anaesthesia with nupercaine and procaine: a comparative study. Ann Surg 1931;94:934-938.

15. Ruben JE, Kistler EM. An evaluation of hypobaric pontocaine for spinal anesthesia with a report of 200 cases. Anesthesiology 1949;10: 621-64.

16. Adams BW. Lignocaine spinal analgesia in transurethral prostatectomy. Anaesthesia 1956;11:297-302.

17. Bouchacourt V. Causas de fallas del bloqueo subaracnóideo; formas de evitarlas. Anest Analg Reanim 2005,20:31-37.

18. Stienstra R, Veering BT. Intrathecal drug spread: is it controllable? Reg Anesth Pain Med 1998;23:347-351.

\section{RESUMEN}

Praxedes H, Oliva Filho AL - Fallos en la Anestesia Subaracnoidea.

JUSTIFICATIVA Y OBJETIVOS: Bier ya describía los fallos en la anestesia subaracnoidea que causa la incomodidad al paciente, y que se da, eventualmente, incluso con la presencia de profesionales hábiles que la hayan conducido de forma técnicamente correcta. Existe una variación, sin embargo, del concepto de fallo y principalmente, de la identificación precisa de las causas. El objetivo del trabajo es identificar mejor las causas de esa incomodidad a través de la revisión sistemática de publicaciones con casuística significativa.

CONTENIDO: El análisis se dividió en tres tópicos: la anatomía y sus variaciones; el agente anestésico, que trata sobre la selección del agente, sus soluciones y añadiduras, para poder alcanzar el resultado más apropiado en la intervención quirúrgica que se propone ejecutar; y la dosis, discutiendo la concentración, el volumen o la dosis gravimétrica, para poder obtener el resultado más adecuado, tanto en lo concerniente a la intensidad del bloqueo, como en lo que respecta a su duración.

CONCLUSIONES: Los fallos son más inherentes a los factores técnicos: la evaluación anatómica adecuada, la elección de criterio de la aguja y del local de la punción, los cuidados en el almacenaje de los agentes, la adecuación de la dosis, la baricidad, además del posicionamiento correcto del paciente durante y después de la punción, todo a tono con el objetivo quirúrgico. 